\title{
Imagens impressas: a Revista do Paraná como suporte das primeiras litografias na Curitiba oitocentista $(1887)^{1}$
}

\section{Printed images: Revista do Paraná as support for the first litographs in Curitiba of the 1800's (1887)}

\author{
Dulce Regina Baggio Osinski* \\ Iriana Nunes Vezzani**
}

\begin{abstract}
Resumo
Este artigo analisa aspectos da introdução das imagens em litografia no Paraná por meio da Revista do Paraná, que circulou em Curitiba em 1887. Publicado pelo professor e jornalista Nivaldo Braga (1852-1924) e ilustrado pelo artista litógrafo catalão Narciso Figueras (1854-?), o periódico é considerado o primeiro na então Província a enfatizar a imagem em sua proposta editorial. Com forte acento regionalista, a Revista do Paraná se relaciona com o esforço de modernização da sociedade paranaense por meio da melhoria de suas oficinas gráficas e da iniciativa de oferecer ao leitor um material gráfico que privilegiava a imagem como elemento de um imaginário em construção. Embora com duração efêmera, a iniciativa inspirou outros projetos editoriais do período, aproximando os leitores da produção de seus artistas por meio da veiculação de retratos de personalidades paranaenses e paisagens locais, e contribuindo para a ampliação de sua visão de mundo.
\end{abstract}

Palavras-chave: Litografia no Paraná; Revista do Paraná; imagem e história.

\begin{abstract}
This article analyses aspects of the introduction of lithographic images in Paraná by the Revista do Paraná, which circulated in Curitiba in 1887. Published by professor and journalist Nivaldo Braga (1852-1924) and illustrated by Catalan lithographist Narciso Figueras (1854-?), the magazine was considered the first in the Province to emphasize the image in its editorial proposal. With a strong regionalist prominence, Revista do Paraná was related with the efforts
\end{abstract}

\footnotetext{
* Doutora em Educação pela Universidade Federal do Paraná. Professora do Departamento de Artes e da linha de pesquisa em História e Historiografia da Educação do Programa de Pós-Graduação em Educação da Universidade Federal do Paraná. E-mail: dulceosinski@gmail.com

${ }^{* *}$ Mestre em Educação e doutoranda na linha de pesquisa em História e Historiografia da Educação do Programa de Pós-Graduação em Educação do Paraná. E-mail: irianazz@yahoo.com.br

${ }^{1} \mathrm{O}$ presente texto é resultado do aprofundamento das reflexões inicialmente apresentadas e publicadas nos anais do $22^{\circ}$ Encontro Nacional da ANPAP, ocorrido em 2013 em Belém, PA.
} 
to modernize Paraná's society through the improvement of its print shops and by offering its readers graphic material that privileged image as an element of in-the-make imagination. Although it was short lived, the idea inspired other published material in that period, bringing readers closer to their artists' production by printing pictures of Paraná VIPs and local landscapes, and contributing to enhancing their views on the world.

Keywords: Lithography in Paraná; Revista do Paraná; Image and History.

\section{Introdução}

Pensar a produção de gravuras em perspectiva histórica significa enfrentar as imbricações entre a dimensão artística das imagens produzidas e seu escopo utilitário. Para além das investigações de caráter estético, desde sua introdução na Europa em meados do século XIV, os processos de xilogravura e gravura em metal serviram à reprodução de todos os tipos de imagem, como mapas, ilustrações científicas, literárias e obras de arte. 0 mesmo aconteceu com a litografia, a qual, inventada e patenteada por Alois Senefelder em 1798, revolucionou os meios de comunicação da época. A partir dela, a gravura atingiu seu ponto mais importante como suporte para as imagens de consumo, viabilizando "uma série de demandas e exigências geradas pela revolução industrial". ${ }^{2}$

A técnica litográfica apresenta maior complexidade quando comparada à xilografia e à gravura em metal, pois, ao contrário destas, a gravação e a impressão não se baseiam na diferença de planos da matriz, mas no processo físico-químico de acidulação e no fenômeno de atração e repulsão entre água e gordura. Em vez de ser entalhada ou corroída com ácidos, a matriz, uma pedra calcária, é sensibilizada por tintas e lápis gordurosos, procedimento que provocou mudanças importantes na produção da imagem. A proximidade com o desenho na fase de elaboração da imagem permitiu que o artista se ocupasse pessoalmente da gravação por ele concebida, prescindindo da interferência do gravador em seu desenho original.

${ }^{2}$ FABRIS, Annateresa. Fotografia: usos e funções no século XIX. São Paulo: Editora da Universidade de São Paulo, 2008, p. 12. 
As imagens impressas, praticamente idênticas à original, davam assim início à informação visual de primeira mão. Conforme afirma o filósofo alemão Walter Benjamin,

Com a litografia, a técnica de reprodução atinge uma etapa essencialmente nova. Esse procedimento muito mais preciso, que distingue a transcrição do desenho numa pedra de sua incisão sobre um bloco de madeira ou uma prancha de cobre, permitiu às artes gráficas pela primeira vez colocar no mercado suas produções não somente em massa, como já acontecia antes, mas também sob a forma de criações sempre novas. Dessa forma, as artes gráficas adquiriram os meios de ilustrar a vida cotidiana. Graças à litografia, elas começaram a situar-se no mesmo nível que a imprensa. ${ }^{3}$

Esses fatores, aliados às facilidades de impressão, fizeram da litografia uma técnica revolucionária, impulsionando o avanço na indústria gráfica do século XIX. Segundo Hauser, sua introdução transformou a história dos processos de reprodução de imagens e está ligada de forma direta à democratização da fruição da arte, implicando a vitória "do gosto popular e do jornalismo num nível incomparavelmente mais elevado". 4

No século XIX, pôde-se assistir aos primeiros sinais de um processo que Salgueiro chamou de "dessacralização da imagem":

[...] em que tem início o crescente mercado da literatura ilustrada, o romance de folhetim, os clássicos reeditados com figurinhas e vinhetas, os livros de bolso avant la lettre, os livros dos viajantes [...]; os anúncios, os cartazes, enfim, a comunicação visual e a publicidade facilitadas pela reprodução mecânica que caracteriza esse tempo de leitura "a vapor" [...] quando o livro muda de estatuto, rompendo os laços com o sistema de representação anterior. ${ }^{5}$

Amplamente utilizada ao longo do século XIX e início do século XX, a técnica litográfica facilitou o encontro entre a imagem e a palavra escrita, fazendo com que jornais, revistas, enciclopédias e livros ilustrados absorvessem novas possibilidades de expressão do conhecimento. ${ }^{6}$ Produzidas pelos artistas, as imagens contidas nesses veículos em gravura ou em fotografia

\footnotetext{
${ }^{3}$ BENJAMIN, Walter. A obra de arte na era de sua reprodutibilidade técnica (Primeira versão). In: Magia e técnica, arte e política: ensaios sobre literatura e história da cultura (Obras escolhidas, v. 1). Tradução: Sérgio Paulo Rouanet. 7. ed. São Paulo: Brasiliense, 1994, p. 166-167.

${ }^{4}$ HAUSER, Arnold. História Social da Arte e da Literatura. Tradução: Álvaro Cabral. 1. ed. (4a tiragem). São Paulo: Martins Fontes, 1998, p. 796.

${ }_{5}^{5}$ SALGUEIRO, Heliana Angotti. A comédia urbana: de Daumier a Porto-Alegre. 1. ed. São Paulo: Fundação Álvares Penteado, 2003, p. 35.
}

${ }^{6}$ SANTAELLA, Lucia. Leitura de imagens. 1. ed. São Paulo: Melhoramentos, 2012. 
alcançavam um público amplo, penetrando no cotidiano do leitor comum e mudando sua percepção de mundo.

O fortalecimento da imprensa foi um fator constitutivo da modernidade do final do século XIX, que tinha como uma de suas notas dominantes o entusiasmo pelos progressos técnicos. Segundo Allan Bullock, ${ }^{7}$ o período que antecedeu a Primeira Guerra Mundial, especialmente entre 1870 e 1913, foi o de maior crescimento econômico na história, contando com um aumento da produção industrial, ao qual se somava uma revolução tecnológica sem precedentes. A experiência moderna, que veio acompanhada "de uma paisagem de engenhos a vapor, fábricas automatizadas, ferrovias, amplas novas zonas industriais, prolíficas cidades que cresceram do dia para a noite", ${ }^{8}$ também fomentou a disseminação dos jornais diários e de outros instrumentos de media.

O processo de modernização, "fenômeno complexo, de amplo fôlego e multidimensional, que acontece em períodos diferentes e em todos os setores do sistema social", teria como características, de um lado, "a tentativa do homem em controlar a natureza e sujeitá-la às suas necessidades" e, de outro, "o esforço perene de ampliar o âmbito das opções sociais e políticas para o maior número de pessoas". ${ }^{9}$ Nesse sentido, os veículos impressos configuravam-se em meios estratégicos, contribuindo para a mobilização de um número cada vez mais crescente de indivíduos em torno de interesses comuns.

Atuando como instrumentos de registro do momento histórico, as revistas do período cumpriram também o papel de agentes da história, sendo, na época, quase incontável o número de publicações em circulação, mesmo com duração e periodicidade variáveis. Suas contribuições para os processos de modernização geraram mudanças não só nos modos de impressão mas também na própria forma de redação, ampliando o universo letrado para um mundo que se abria também à forma visual. As revistas ilustradas eram um convite sedutor à leitura: comunicavam instruções e sugeriam modos de pensar e de agir, ${ }^{10}$ possibilitando uma leitura de ordem mais reflexiva para além dos textos escritos.

\footnotetext{
${ }^{7}$ BULLOCK, Allan. A dupla imagem. In: BRADBURY, Malcolm; McFARLANE, James (org.). Guia Geral do Modernismo. Tradução: Denise Botmann. 1. ed. (2 reimpressão). São Paulo, Companhia das Letras, 1989 , p. 45. ${ }^{8}$ BERMAN, Marshall. Tudo o que é sólido desmancha no ar: a aventura da modernidade. Tradução: Carlos Felipe Moisés; Ana Maria L. Ioratti. 1. ed. São Paulo: Companhia das Letras, 2007, p. 45.

${ }^{9}$ BOBBIO, Norberto; MATTEUCCI, Nicola; PASQUINO, Gianfranco. Dicionário de política. Tradução: João Ferreira (coord.). 11. ed. Brasília: UnB, 1998, p. 768.

${ }^{10}$ BOURDIEU, Pierre; A Leitura: Uma prática cultural (Debate entre Pierre Bourdieu e Roger Chartier). In: CHARTIER, Roger (org.). Práticas da Leitura. Tradução: Cristiane Nascimento. 2. ed. São Paulo: Estação Liberdade. 2001, p. 234.
} 
No contexto brasileiro da segunda metade do século XIX, palavra e imagem impressas ganharam força e expressão com experiências de periódicos ilustrados produzidos por agentes sociais diversos, que atuaram em prol do que se pretendia ser o projeto civilizatório do Império. Esses periódicos se apoiavam nos jornais caricatos que faziam sucesso na Europa, tendo sido introduzidos no Rio de Janeiro por Manoel de Araújo Porto-Alegre (1806-1879) a partir do conhecimento dessa prática em Paris. ${ }^{11}$ Estudos recentes apontam ilustradores e litógrafos como responsáveis pela produção e difusão das imagens no período, destacando a importância do papel econômico, social e cultural dessa indústria que sensibilizou o público para um universo imagético, criando assim uma demanda crescente, que exigia aperfeiçoamento contínuo e tratamento industrial. ${ }^{12}$

Embora antes de 1860 já circulassem no Rio de Janeiro alguns periódicos ilustrados pela técnica da xilogravura, a imprensa ilustrada só despontou após esta década, pela dificuldade de se incluir texto e imagem na mesma página com impressão simultânea e pela falta de mão de obra qualificada para a transposição das imagens. ${ }^{13}$

A pertinência das revistas como testemunhos do período é válida se levarmos em consideração as condições de sua produção, de sua negociação e de seu mecenato propiciador. ${ }^{14}$ Inseridos e atuantes num período da história do Brasil marcado por manifestações políticas e culturais, de debates entre monarquistas e republicanos, entre intelectuais, artistas, escritores e educadores de diversas áreas, esses impressos constituem fontes por meio das quais é possível observar como se organizavam as vozes dentro desse contexto, refletindo ecos das inquietações locais daquele momento.

Para transitarmos pelo território da visualidade, é preciso considerar a imagem como representação visual e, como tal, artificialmente criada, produzida e reproduzida. ${ }^{15}$ Pinturas, desenhos, fotografias ou filmes, entre outros, são registros com os quais os historiadores devem manter um diálogo

\footnotetext{
${ }^{11}$ LUCA, Tania Regina de. A grande imprensa na primeira metade do século XX. In: MARTINS, Ana; LUCA, Tania Regina de. História da imprensa no Brasil. 1. ed. São Paulo: Contexto, 2008, p. 46-65.

${ }^{12}$ TELLES, Angela Cunha da Motta. Desenhando a Nação: revistas ilustradas do Rio de Janeiro e de Buenos Aires nas décadas de 1860-1870. 1. ed. Brasília: Fundação Alexandre Gusmão, 2010, p. 22.

${ }^{13}$ AZEVEDO, Sílvia Maria. Brasil em Imagens: um estudo da revista Ilustração Brasileira (1876-1878). 1. ed. São Paulo: Ed. UNESP, 2010, p. 12.

${ }^{14}$ MARTINS, Ana Luiza. Revistas em revista: Imprensa e Práticas Culturais em Tempos de República. São Paulo (1890-1922). 1. ed. São Paulo: Editora da Universidade de São Paulo: Fapesp, 2008, p. 21.

${ }^{15} \mathrm{JOLY}$, Martine. Introdução à análise da imagem. Tradução: José Eduardo Rodil. 1. ed. Rio de Janeiro: Edições 70, 2007; SANTAELLA, Lucia. op. cit.
} 
contínuo, pois trazem embutidas as escolhas do produtor e todo o contexto no qual foram concebidas, idealizadas, forjadas ou inventadas. ${ }^{16}$ Elas registram, segundo Burke, "atos de testemunho ocular", os quais nos falam não necessariamente sobre o mundo social em si, mas sobre as visões contemporâneas daquele mundo, precisando sempre ser considerados em seus respectivos contextos. Assim como acontece com os textos escritos, também no caso das imagens o historiador "necessita ler nas entrelinhas, observando os detalhes pequenos mas signicativos - incluindo ausências significativas - usando-os como pistas para informações que os produtores de imagens não sabiam que eles sabiam, ou para suposições que eles não estavam conscientes de possuir". ${ }^{17}$

Para o autor, a análise dos diferentes tipos de imagem deve levar necessariamente em conta duas revoluções relacionadas à sua produção: o surgimento da imagem impressa, que começou no Ocidente no século XIV com a xilogravura e que, ao longo do tempo, também agregou em seu repertório a gravura em metal, a litografia, a serigrafia, a impressão em off-set e, mais recentemente, os métodos de impressão digital e a invenção dos meios fotográficos de imagem, que incluem ainda o filme e a televisão. Essas revoluções possibilitaram às pessoas comuns um maior acesso às imagens, o que trouxe consequências culturais significativas.

As imagens selecionadas para comporem os conteúdos das revistas revelam muito de uma época. Por meio das páginas da Revista do Paraná é possível entrever aspectos da sociedade curitibana da época e saber um pouco sobre seu pensamento, seus valores e também sobre suas aspirações e desejos.

\section{Uma revista com litografias para o Paraná}

Segundo a historiadora da arte Maria José Justino, ${ }^{18}$ a modernidade não pode ser pensada de acordo com modelos únicos estabelecidos, pois cada sociedade cria e define seus paradigmas. A ideia de moderno tampouco pode ser fixada temporalmente, pois, de acordo com Bradbury e MacFarlane, "a modernidade, na acepção usual da palavra, é algo que avança com os anos, acompanhando sua velocidade, como a curva ondulação de um barco; o moderno do ano passado não é o moderno deste ano". ${ }^{19}$ Portanto, assim como

\footnotetext{
${ }^{16}$ PAIVA, Eduardo França. História \& imagens. 1, ed. Belo Horizonte: Autêntica, 2002, p. 17.

${ }^{17}$ BURKE, Peter. Testemunha ocular: História e imagem. Tradução: Vera Maria Xavier dos Santos. 1. ed. Bauru, SP: EDUSC, 2004, p. 238.

${ }^{18}$ JUSTINO, Maria José. Brasilidade II: A idade da razão. Gazeta do Povo, Curitiba, 30 out. 1995. Caderno G.

${ }^{19}$ BRADBURY, Malcolm; McFARLANE, James (org.). Guia Geral do Modernismo. Tradução: Denise Botmann. 1. ed. (2 reimpressão). São Paulo, Companhia das Letras, 1989, p. 15.
} 
os aspectos temporais precisam ser relativizados, também as peculiaridades geográficas relacionadas ao fenômeno moderno devem ser levadas em conta para uma melhor compreensão de determinados contextos.

No que se refere ao Paraná, a partir de sua emancipação política, efetivada em 1853, investimentos começaram a ser feitos de forma mais sistemática com vistas à melhoria da comunicação em seu território. Em 1873, foram concluídas as obras da Estrada da Graciosa, ligando o litoral e o planalto pela Serra do Mar. Já a Estrada de ferro Paranaguá-Curitiba foi inaugurada oficialmente em 1885, possibilitando maior fluxo de comércio entre as duas cidades, com outros estados e mesmo com o exterior. ${ }^{20}$ Movida pela indústria do beneficiamento da erva-mate, principal produto de exportação do Paraná à época, a capital Curitiba se urbanizava e atraía um fluxo migratório cada vez maior, provocando aumento da população e demandando melhorias, como a criação de praças e avenidas, o calçamento das vias públicas, a construção de galerias pluviais e a criação de linhas de bondes elétricos. ${ }^{21}$ Esse movimento resultou na diversificação da economia, que passou a contar também com algumas fábricas de cerveja e pequenos estabelecimentos manufatureiros.

Além disso, construções de maior porte se encontravam em processo. Em 1874, as obras do Hospital da Santa Casa de Misericórdia estavam em andamento e o mercado novo já estava concluído. ${ }^{22}$ Com relação às iniciativas educacionais, esforços eram feitos no sentido de equipar a capital com instituições nos diversos níveis de ensino. Em 1876, foi criado o Instituto Paranaense, de ensino secundário, em substituição ao Liceu de Curitiba, fundado em 1846 e extinto em 1874, e anexo à Escola Normal. ${ }^{23}$ No campo artístico-cultural, Curitiba contava com o Teatro São Theodoro, inaugurado em 1884 e que oferecia à população espetáculos teatrais e musicais. A partir de 1886, o artista português Mariano de Lima deu início à sua Escola de Desenho e Pintura, a qual era gratuita e atendia homens e mulheres no período noturno. Inaugurada oficialmente em 6 de janeiro de 1887, a instituição era subsidiada pelo Governo e daria origem à criação, em 1897, da Escola de Belas Artes e Indústrias do

\footnotetext{
${ }^{20}$ DICIONÁRIO Histórico-Biográfico do Paraná. 1. ed. Curitiba: Chain; Banco do Estado do Paraná, 1991, p. 141. ${ }^{21}$ BONI, Maria Ignês Mancini de. O espetáculo visto do alto. Vigilância e punição em Curitiba (1890-1920). São Paulo: Tese de Doutorado, área de História, Universidade de São Paulo, 1998, p. 11-46.

${ }^{22}$ CARNEIRO, Newton Issac da Silva. A arte paranaense antes de Andersen. Boletim Informativo da Casa Romário Martins. Curitiba, ano VII, nº 43, 1980, p. 11.

${ }^{23}$ ZACHARIAS, Mariana Rocha. Espaços e Processos Educativos do Ginásio Paranaense: Os ambientes especializados e seus artefatos (1904-1949). Dissertação de Mestrado, Programa de Pós-graduação em Educação, Universidade Federal do Paraná, 2013, p. 24.
} 
Paraná, ${ }^{24}$ que contou com o apoio da intelectualidade paranaense e marcaria a vida cultural local.

A imprensa mereceu investimentos paulatinos a partir da criação da Província do Paraná. A cidade contava com serviços tipográficos desde 1854, quando Candido Martins Lopes inaugurou a Typographia Paranaense, que possibilitou a edição do primeiro número do jornal o Dezenove de Dezembro. Vários periódicos foram editados neste período, a exemplo do Jasmim, de caráter literário e recreativo, que veio à luz em 1857; do Mascarado, órgão crítico impresso, publicado a partir de 1860; e de outros, como o Clarim e o Constitucional, de 1861, ou a Imprensa Livre, de 1867. Outras iniciativas também movimentavam as discussões culturais e políticas das rodas curitibanas. É o caso de A Phenix, de 1866; O Paraná e A Reforma, de 1871; a Iris Paranaense, de 1873; Província do Paraná, O Paranaense, 25 de Março e Gazeta Paranaense, de 1876; o Diabo Azul, de 1878; ou a Revista Paranaense, de 1881..$^{25}$

Entretanto, na Curitiba de 1880, o desejo de ser moderno passava igualmente pela revigoração dos meios gráficos locais, o que fez com que o carioca Luiz Coelho, proprietário da primeira livraria da cidade e frequentador de rodas literárias, colocasse para funcionar o primeiro prelo mecânico, o que implicou a melhoria da qualidade e a ampliação das possibilidades de publicações no Paraná. ${ }^{26}$ Essa inovação foi responsável pelo surgimento de mais de dez periódicos entre 1882 e 1883, tais como o Pássaro Azul, O Imparcial, o Jornal do Commercio. Já em 1884, o Dezenove de Dezembro se tornou a primeira folha a circular diariamente, e, em 1885, foram criados A Jangada, Gazeta de Curityba e Echo Paranaense. O Jornal A República, surgido em 1886, tinha como missão a propagação do ideal antimonarquista. ${ }^{27}$ Apesar de todas essas conquistas, informado sobre os recursos disponíveis em centros como o Rio de Janeiro, Coelho aspirava a uma oficina litográfica para o seu projeto de modernização, e isso só se tornaria possível em 1884, com a chegada a Curitiba do bacharel em belas artes, ilustrador e litógrafo catalão Narciso Figueras.

\footnotetext{
${ }^{24}$ SANTANA, Luciana Wolff Apolloni. Escola de Belas Artes e Indústrias do Paraná: o projeto de ensino de artes e ofícios de Mariano de Lima. Curitiba, 1886-1902. Dissertação de Mestrado, Programa de Pós-graduação em Educação, Universidade Federal do Paraná. 2004, p. 24-45.

${ }_{25}$ PILOTTO, Osvaldo. Cem anos de imprensa no Paraná (1854-1954). 1, ed. Curitiba: Instituto Histórico Geográfico e Etnográfico Paranaense, Estante Paranista, 1976, p. 8-13.

${ }^{26}$ MELLO, Sílvia Gomes Bento de. Esses moços do Paraná: Livre circulação da palavra nos albores da República. Florianópolis: Tese de doutorado. Programa de Pós-Graduação em História Cultural, Linha de Pesquisa Políticas da Escrita, da Imagem e da Memória, Universidade Federal de Santa Catarina, 2008, p. 158.

${ }^{27}$ PILOTTO, op. cit., p. 14.
} 
Nascido em Gerona, na Espanha, Figueras residira em Cuba antes de vir ao Brasil, tendo atuado como ilustrador de importantes revistas do Rio de Janeiro, como Entre'acto, Bohemio e a Comédia. ${ }^{28}$ Atraído pelas possibilidades de aplicar a técnica de impressão de imagens nas publicações locais, o artista abriu, em 1885, a Lithographia do Commércio, situada na rua Trajano Reis, "em cujas dependências montou um ateliê de iconografias, onde se formaram os primeiros litógrafos do estado". ${ }^{29}$ Como ilustrador de periódicos, ${ }^{30}$ Figueras foi também responsável pelo surgimento de toda uma geração de caricaturistas e ilustradores. Atuando na formação de profissionais em seu próprio estabelecimento, orientou jovens artistas, como o escritor e jornalista Silveira Netto (1872-1942), os quais aprendiam o ofício na prática cotidiana da oficina. ${ }^{31} \mathrm{Em}$ anúncio publicado na imprensa local, a Lithographia do Commércio afirmava encarregar-se "de ilustrações de jornaes, dezenhos, mapas e todo e qualquer trabalho concernente a esta arte", ${ }^{32}$ descrevendo as oficinas do estabelecimento como

[...] montadas a capricho, possuindo todos os melhoramentos modernos admittidos na arte litographica, dispondo de excellentes machinas para todos os trabalhos de impressão, gravura, corte e perfuração e papeis, variadíssimo sortimento de papeis, tintas, cartões e um pessoal habilitado a desempenhar qualquer obra. ${ }^{33}$

Uma oficina litográfica poderia ser uma via de acesso ao progresso da capital da Província do Paraná, e o estabelecimento de Figueras ofereceu as condições necessárias para que o educador e jornalista paranaense Nivaldo Braga (1852-1924) criasse, em 1887, a Revista do Paraná, considerada o primeiro periódico ilustrado da Província, na qual a imagem desempenhava papel de destaque junto às matérias escritas. Com essa iniciativa, Curitiba se inseria

\footnotetext{
${ }^{28}$ CARNEIRO, Newton Issac da Silva. Surto e desenvolvimento das astes gráficas em Curitiba. 1. ed. Curitiba: Edições Paiol, 1975, p. 35.

${ }^{29}$ PEREIRA, Luís Fernando Lopes. O espetáculo dos maquinismos modernos: Curitiba na virada do século XIX ao XX. Dissertação de mestrado em História, Universidade de São Paulo, 2002, p. 49.

${ }^{30}$ Além das publicações Entre'acto, Bohemio, a Comédia e a própria Revista do Paraná, Figueras também ilustrou a Galeria Illustrada e 0 Quinze de Novembro.

${ }^{31}$ MELLO, op. cit., p. 159-160.

${ }^{32}$ REVISTA do Paraná. Curitiba, ano 1, nº 1, 23 out. 1887, p. 8.

${ }^{33}$ LITHOGRAPHIA do Commercio. Revista do Paraná, Curitiba, 23 out. 1887, p. 8.
} 
em um período reconhecido por Lima $^{34}$ como de educação do olhar e de redefinições de valores estéticos. ${ }^{35}$

Braga era professor público oriundo da Lapa e havia fundado em 1879 o Collegio Curitybano, instituição em que viriam a estudar diversas personalidades que fariam história em Curitiba, a exemplo de Sebastião Paraná, Agostinho Ermelino de Leão, Romário Martins, Emiliano Perneta e Dario Vellozo, entre outros. Devido a problemas de ordem política, Braga decidiu abandonar o magistério público e atuar no jornalismo, sendo acolhido por Luiz Coelho na Pêndula Meridional, livraria e tipografia que apoiou sua iniciativa de uma publicação diferenciada. ${ }^{36}$ Naquele mesmo ano, ele também daria início, com adesão da elite intelectual local, à "Arcádia Paranaense", uma associação promotora de festividades literárias que tinha por finalidade a comemoração das épocas mais notáveis da história da Província. ${ }^{37}$

O engajamento de Nivaldo Braga com seus projetos editoriais é expresso em declaração de 15 de outubro daquele ano, publicada na primeira edição da Revista do Paraná, na qual ele afirma estar se retirando do Partido Conservador e desistindo da candidatura à Assembleia Legislativa Provincial para poder se dedicar à sua publicação. Inclui também no argumento o seu envolvimento com o projeto do Dicionário Geográfico, Histórico, Biográfico e Descritivo da Província, ${ }^{38}$ para cujo fim disse estar montando uma oficina. ${ }^{39}$

O primeiro número da Revista do Paraná saiu em 23 de outubro de 1887, e, segundo Newton Carneiro, ela concorria em qualidade com "as melhores revistas brasileiras e até dos grandes centros do mundo" ${ }^{40}$ no período em que circulou. Esse cuidado gráfico e com as imagens, segundo Mello, ${ }^{41}$ desestabilizava a soberania da palavra escrita. Embora acolhido com entusiasmo pela sociedade e pelos intelectuais locais, o periódico teve existência curta. Foram publicados apenas sete números, sua última edição datando de 17 de dezembro daquele ano. Essa efemeridade era comum a muitas iniciativas

\footnotetext{
${ }^{34}$ LIMA, Solange Ferraz de. "O circuito social da fotografia: caso II.” In: FABRIS, Annatereza. Fotografia: Usos e Funções no Século XIX. 1. ed. São Paulo: Editora da Universidade de São Paulo, 2008, p. 68.

${ }^{35}$ FABRIS, op. cit., p. 33.

${ }^{36}$ MELLO, op. cit., p. 170.

${ }^{37}$ DICIONÁRIO Histórico-Biográfico do Paraná. op. cit., p. 42.

${ }^{38}$ Não há indícios que tenha sido finalizado, tendo sido aventada a hipótese de que os originais tenham se perdido Ver: DICIONÁRIO Histórico-Biográfico do Paraná. op. cit., p. 42.

${ }^{39}$ BRAGA, Nivaldo. Declaração. In: Revista do Paraná, Curitiba, ano 1, nº 2, 30 out. 1887, p. 7.

${ }^{40}$ CARNEIRO, op. cit., p. 35.

${ }^{41}$ MELLO, op.cit., p. 172.
} 
congêneres do período, pois as dificuldades financeiras causadas pela falta de financiamento externo e pela insuficiência de anunciantes, especialmente em centros de menor porte como Curitiba, somavam-se às de caráter técnico, como a carência de mão de obra especializada, na época exercida muitas vezes por profissionais estrangeiros, ou o alto custo do papel, que tinha de ser importado. ${ }^{42}$ Além disso, os conteúdos desse tipo de periódico tinham caráter de maior aprofundamento se comparados aos dos jornais contemporâneos, sendo dirigidos a uma elite letrada e restrita em relação à população como um todo. ${ }^{43}$

Sensível ao momento cultural vivido por Curitiba, movimentada pela "fundação de grêmios artísticos, oficinas artesanais, associações recreativas, entidades assistenciais de toda sorte", ${ }^{44}$ Nivaldo Braga idealizou uma publicação voltada às questões locais, nela atuando como redator-proprietário e a ele cabendo a seleção das matérias e das ilustrações. Além dos textos sem assinatura, assumidos como sendo da editoria da revista, outros eram escritos por Braga sob os pseudônimos de "Jacaná", "Yta-uba", "Tong-tong", "Frege-moscas", "Bentevi” ou "Ita-cyuna", aos quais por vezes acrescentava: "repórter da revista". Cabia a Narciso Figueras a gravação das imagens em litografia, todas elas impressas em página inteira em sua oficina, sendo as partes textuais impressas na tipografia de Luiz Coelho.

Com formato de $27,5 \mathrm{X} 38 \mathrm{~cm}$ e periodicidade semanal, como a maioria das revistas do período, ${ }^{45}$ a publicação manteve durante todos os números a mesma diagramação, apresentando o texto em três colunas, ${ }^{46} \mathrm{com} 6,5 \mathrm{~cm}$ cada uma, e as imagens inseridas isoladamente, sempre às páginas 1,4 e 5.0 número de páginas variava entre 8 e 9 , sendo uma delas dedicada a anúncios da Lithographia do Commercio, da tipografia da Revista do Paraná, então em processo de instalação, e da tipografia de Luiz Coelho. O primeiro número teve uma

\footnotetext{
${ }^{42}$ MARTINS, Ana Luiza. Revistas em revista: Imprensa e Práticas Culturais em Tempos de República, São Paulo (1890-1922). São Paulo: Editora da Universidade de São Paulo: Fapesp, 2008.

${ }^{43} \mathrm{Em} 1890$ o Paraná contava com uma população de 249.489 habitantes, dos quais 35.324 pessoas $(14,1 \%)$ eram escolarizáveis. Dessas, apenas 3.723 pessoas $(10,5 \%)$ frequentavam escola em todo o Estado. Para mais informações, ver: TRINDADE, Etelvina Maria de Castro; ANDREAZZA, Maria Luiza. Cultura e Educação no Paraná. Curitiba: SEED, 2001. Ver também: OLIVEIRA, Maria Cecília Marins de. "Cultura escolar e contexto social do Paraná na primeira República”. Plures - humanidades. Ribeirão Preto. Vol. 3, nº 1. 2002.

${ }^{44}$ CARNEIRO, Newton Issac da Silva. Revista do Paraná. In: Revista do Paraná - 1887. Edição Fac-similar. Curitiba, 1981.

${ }^{45}$ TELLES, op. cit., p. 38.

${ }^{46} \mathrm{O}$ número de colunas da revista, tornando a página mais leve visualmente, se diferenciava dos jornais do período, que trabalhavam com os textos dispostos em cinco colunas, privilegiando o texto escrito em detrimento das imagens.
} 
tiragem de mil exemplares e a assinatura semestral custava cinco mil réis, sendo um exemplar avulso vendido pela soma de quinhentos réis. ${ }^{47}$ Analisando os originais pertencentes ao Instituto Neopitagórico, a pesquisadora Cassiana Lacerda Carollo ${ }^{48}$ observou a recorrência de ilustrações impressas em tons sépia, verde-claro e cinza, numa possível tentativa, por parte da editoria, de tornar os exemplares atraentes ao público leitor.

Relatando a recepção da Revista do Paraná por parte da imprensa e de setores da sociedade, e também como um modo de fazer propaganda do empreendimento, a seção "Ineditoriaes" transcreveu um trecho de matéria veiculada no jornal Dezenove de Dezembro, a qual descrevia o periódico como nitidamente impresso e redigido em linguagem "elevada e digna da causa a que se destina". Também mencionava o fato de os assinantes serem em sua maioria estrangeiros, dizendo que isso era um modo de "engrandecer o Paraná". ${ }^{49} \mathrm{O}$ interesse de outras cidades como a Lapa e Palmas também era citado, levando a crer que a circulação do periódico no âmbito paranaense se dava para além dos limites da capital.

Em texto de abertura da Revista, Nivaldo Braga, citando genericamente os escritores de seu tempo, ressaltou a importância da imprensa, considerada como um "terceiro poder do Estado" 50 :

Ella age sobre o animo da massa popular, dirigindo-lhe a opinião, acerca dos acontecimentos côetanos, cuja contemporaneidade estiver sob a acção do dominio publico, do mesmo modo que Neptuno, no Paganismo, actuára outr'hora sobre as ondas oceânicas, incitando ou acalmando as tempestades athmosphericas. ${ }^{51}$

Há um certo exagero nas afirmações do editor, tendo em vista que, embora no final do século XIX a imprensa houvesse se expandido consideravelmente, ainda não poderia ser qualificada como veículo de massa. Entretanto, é interessante observar que, mesmo utilizando em seu discurso argumentos

\footnotetext{
${ }^{47}$ REVISTA do Paraná. Curitiba, ano 1, n 3, 06 nov. 1887, p. 7.

${ }^{48}$ CAROLLO, Cassiana. Nota editorial. In: Revista do Paraná - 1887. Edição Fac-similar. Curitiba, 1981.

${ }^{49}$ REVISTA do Paraná. Curitiba, ano 1, n² 3, 06 nov. 1887, p. 6-7.

${ }^{50} \mathrm{~A}$ alusão feita pelo autor tem relação com a ideia da imprensa como o "quarto poder do estado", surgida no contexto das revoluções liberais ainda no final do século XVIII. Essa ideia deriva do ideal iluminista, que defendia, além da liberdade de expressão individual, também "uma imprensa independente, livre da censura do Estado, formadora da opinião pública e exercendo o papel de 'contrapoder' em relação aos três poderes concebidos por Montesquieu - o Executivo, o Legislativo e o Judiciário”. Ver: LIMA, Venício. A ilusão do quarto poder. Disponível em: http://www.teoriaedebate.org.br/colunas/midia/ilusao-do-quarto-poder. Acesso em: 20 mai. 2015.

${ }^{51}$ REVISTA do Paraná. Curitiba, ano 1, nº 1, 23 out. 1887, p. 2.
} 
absorvidos baseados em referências da experiência de grandes centros, mais especificamente a Europa e os Estados Unidos, Braga já reconhecia e assumia, no projeto editorial da revista, seu poder na mobilização dos leitores em debates sobre assuntos de interesse geral.

Considerada por Habermas ${ }^{52}$ um dos vetores da modernidade, na qual os sujeitos são capazes de construir e manifestar uma opinião sobre questões relevantes para o seu meio social, a imprensa seria ainda, segundo Nivaldo Braga, um "pseudo abductor moral e político", devendo, assim, ser cultuada. Apesar disso, o editor afirmaria ainda que a revista se manteria "neutra na lucta política dos partidos militantes”, o que não significava abrir mão de criticar, "sem nunca descer a offensas pessoaes, e somente em thése, os seus erros e desmandos, ou applaudir, encarecer e encomiar as suas acções meritórias". Sua redação seria confiada à "collaboração de pessoas dignas de uma tal commissão, advogando, em linguagem commedida, porém franca, imparcial, impávida e austera, os interesses da Província". ${ }^{53}$

Como modelos para a Revista do Paraná, foram citadas por Braga as publicações Le Tour du Monde, Novo Mundo e Correio do Recife, as duas primeiras de circulação no exterior. Criado por Édouard Charton em 1857, Le Tour du Monde, editado pela livraria Hachette, de Paris, era um semanário que consagrava seus conteúdos às viagens e às explorações e afirmava contar com as ilustrações dos mais célebres artistas da França. ${ }^{54}$ Já o jornal Novo Mundo, que circulou entre 1870 e 1879, era publicado em língua portuguesa em Nova Iorque pelo advogado José Carlos Rodrigues e enviado periodicamente ao Brasil, tendo contado, de acordo com Asciutti, "com um grupo de colaboradores que, nutrindo admiração pelos rumos do desenvolvimento da nação norte-americana, acreditavam no modelo estadunidense como solução para os problemas sociais brasileiros". ${ }^{55}$ Por sua vez, o pernambucano Correio do Recife, editado por Franz Carls ${ }^{56}$ a partir de 1859, foi o pioneiro no uso de litografias na imprensa

\footnotetext{
${ }^{52}$ HABERMAS, Jürgen. Mudança estrutural da esfera pública: investigações quanto a uma categoria da sociedade burguesa. Tradução: Denilson Luís Werle. 1. ed. São Paulo: Unesp, 2014.

${ }^{53}$ REVISTA do Paraná. Curitiba, ano 1, nº 1, 23 out. 1887, p. 2.

${ }^{54}$ GALLICA. Bibliotèque Numérique. Le tour du Monde. Disponível em: http://gallica.bnf.fr/ark:/12148/ bpt6k34377z/f4.image.langPT. Acesso em: 10 jan. 2015.

${ }^{55}$ ASCIUTTI, Mônica Maria Rinaldi. Um lugar para o periódico O Novo Mundo - Nova Iorque, (1870-1879). São Paulo: Dissertação de Mestrado em Literatura Brasileira, Universidade de São Paulo, 2010, p. 8.

${ }^{56}$ Franz Heinrich Carls, desenhista, fotógrafo e artista gráfico alemão que chegou ao Brasil em 1859, mais precisamente na cidade do Recife, onde fundou em Pernambuco a Casa Litographica, uma das primeiras do gênero. Utilizando pioneiramente litografias na imprensa, ele produziu um número expressivo de imagens que retratam as paisagens pernambucanas do século XIX, as quais foram publicadas no jornal Correio do Recife. Ver mais em: SILVA, Frederico Fernando Souza. Franz Carls: Memórias Litográficas do
} 
brasileira. Essas referências a periódicos possivelmente conhecidos de alguns dos leitores eram uma maneira de conferir à iniciativa credibilidade e respeito, demonstrando sua inserção no mundo dos impressos. Editando uma revista, o editor optava por um gênero com características de transição entre o jornal e o livro, conforme afirmava a Revista Brazileira alguns anos antes:

Na Revista dão-se a ler, sem risco de cansaço, artigos sobre todos os conhecidos assuntos por onde anda o pensamento, a imaginação, a análise, o ensino do homem. Não se trata ali de uma só matéria, como de ordinário no livro singular, ou de muitas matérias em rápido percurso como no jornal, mas de todas com a conveniente demora, em forma de extensão, proporcionada aos espíritos [...], qualquer que seja o grau de instrução de cada um, a intensidade de sua convicção, as tendências de seu gosto, a ordem de seu interesse. ${ }^{57}$

Com relação aos assuntos tratados, Braga declarou que a revista seria consagrada aos interesses gerais e locais da Província, ao clero paranaense, às ciências, letras, artes e indústrias, e às publicações "ineditoriaes, tais como annuncios, avisos, etc" ${ }^{58}$ Esses assuntos eram abordados em seções como a "Galeria Paranaense", dedicada a biografias de paranaenses e assuntos regionais; "Alviçaras”, responsável pelas notícias da cidade; "Seção religiosa”, que contemplava biografias de eminências do clero e monumentos da Igreja; e os próprios "Ineditoriais", com conteúdos mais críticos e satíricos em relação à sociedade paranaense.

O editorial de abertura da Revista do Paraná já dava destaque às imagens que seriam veiculadas, dizendo que tornaria conhecidos, por meio da litografia, os homens notáveis das ciências, letras, artes e indústria, as personalidades da política, do governo e das armas, as principais povoações, os estabelecimentos públicos e industriais, além das paisagens e fenômenos naturais..$^{59}$

\section{Imagens em revista}

Da mesma forma que outros periódicos da época, como a Revista Illustrada, do Rio de Janeiro, em circulação em 1887, ou a Galeria Illustrada, de Curitiba, que circulou em 1888, a Revista do Paraná se fazia identificar por meio

Recife Oitocentista. In: $21^{\circ}$ Encontro Nacional de Pesquisadores em Artes Plásticas - Vida e Ficção / Arte e Fricção, 2012, Rio de Janeiro. Vida e Ficção / Arte e Fricção, 2012, p. 1561.

${ }^{57}$ REVISTA Brazileira, Rio de Janeiro, N. Midosi Editor, 1879, n. 1, p. 19, apud MARTINS, Ana Luiza. Revistas em revista: Imprensa e Práticas Culturais em Tempos de República. São Paulo (1890-1922). 1. ed. São Paulo: Editora da Universidade de São Paulo: Fapesp, 2008, p. 63.

${ }^{58}$ REVISTA do Paraná. Curitiba, ano 1, nº 1, 23 out. 1887, p. 2.

${ }^{59} \mathrm{Idem}$. 
de um frontispício (Figura 1), o qual apresenta, além do título, composto com uma grafia livre e irregular, também uma imagem repleta de conotações simbólicas. Nela, duas mulheres se destacam. A da esquerda, portando uma coroa e segurando um caduceu na mão, símbolo dos conhecimentos relacionados à medicina, poderia estar representando a monarquia, hipótese reforçada pela presença de detalhe do brasão imperial do Brasil do Segundo Reinado, localizado no centro inferior da composição, o qual contradiz a neutralidade política afirmada por Braga. Já a figura da direita poderia ser relacionada com Atenas, deusa grega da sabedoria, pois está rodeada de alguns elementos que representam campos do conhecimento: a engrenagem representando a engenharia, o globo como referência da geografia e a bigorna relacionando-se à metalurgia.

A presença desses elementos denota a intenção inicial, não totalmente concretizada ao longo dos fascículos, de abordar assuntos de caráter mais universal. Ao fundo do frontispício, podemos ver representadas paisagens montanhosas e litorâneas, relacionadas à topografia paranaense. À esquerda, um trem viaja entre as montanhas da Serra do Mar, representando a estrada de ferro Curitiba-Paranaguá, recém-inaugurada. À direita, vê-se o que possivelmente é a baía de Paranaguá. A imagem contém, localizado na parte inferior, o monograma com as letras "NF", iniciais de Narciso Figueras, e a inscrição "Lith do Commercio Coritiba", identificando a oficina e a cidade de procedência. Abaixo dela, em destaque, Nivaldo Braga é identificado não só como diretor da Revista mas também como professor, possivelmente um modo de se impor por meio de uma profissão que, se não era bem remunerada como seria desejável, guardava relações com atividades intelectuais.

Figura 1 - Frontispício da Revista do Paraná60

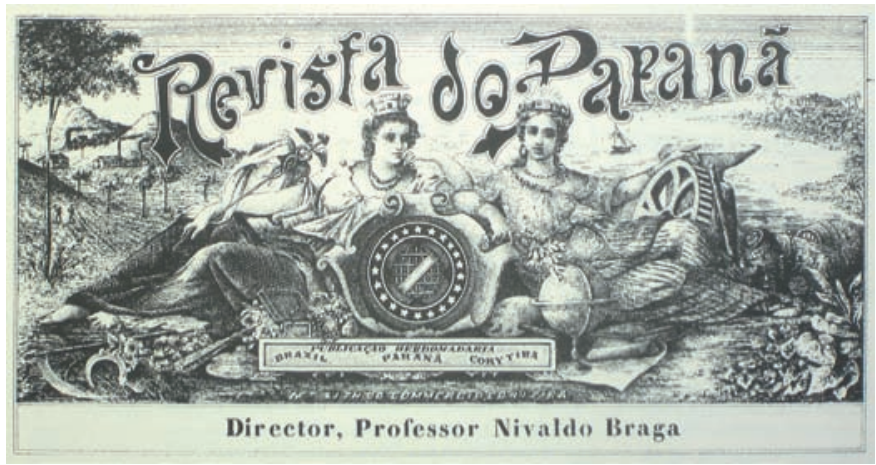

${ }^{60}$ REVISTA do Paraná. Curitiba, ano 1, nº 1, 23 out. 1887, p. 1. 
O frontispício compunha a capa da revista (Figura 2), deixando espaços em branco que estabeleciam a dominância da imagem como recurso para chamar a atenção do olhar do leitor. A página é dividida com espaços entre os textos. O título da revista, integrando o frontispício, fazia também o papel de elemento gráfico. A imagem, hierarquicamente superior ao texto, ocupava ali um lugar de destaque, preenchendo funções para além daquelas meramente ilustrativas, decorativas ou didáticas.

O empreendimento de Nivaldo Braga guarda alguns pontos em comum com a Revista Illustrada, do Rio de Janeiro (Figura 3). As duas apresentavam frontispícios elaborados, embora o da publicação carioca não contivesse imagens, investindo na tipografia e no desenho das letras iniciais. Também se percebe semelhança no modo de organização visual das capas, que se caracterizam pela dominância da imagem em relação ao texto ${ }^{61}$. Embora seja possível afirmar que as iniciativas dos grandes centros brasileiros servissem de modelo para aquelas empreendidas em locais periféricos, a exemplo da capital paranaense, percebe-se um esforço por parte da Revista do Paraná no sentido de atender ao gosto e às necessidades locais. Enquanto o periódico paranaense optava por apresentar retratos de figuras ilustres do Paraná, a Revista Illustrada investia em caricaturas de caráter crítico ou satírico, de cunho político ou social.

Figura 2 - Exemplo de capa da Revista do Paraná, primeiro número ${ }^{62}$.

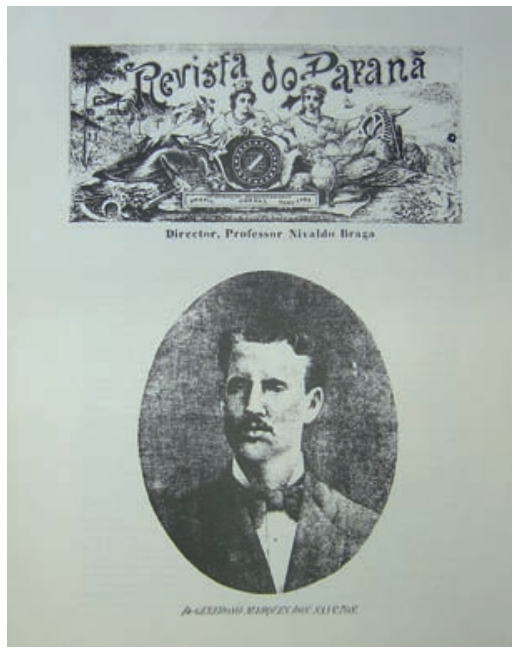

\footnotetext{
${ }^{61}$ Sobre relações de dominância entre texto e imagem, ver: SANTAELLA, op. cit., p. 113.

${ }^{62}$ REVISTA do Paraná. Curitiba, ano 1, nํ1, 23 out. 1887, p. 1.
} 
Figura 3 - Capa da Revista Illustrada ${ }^{63}$

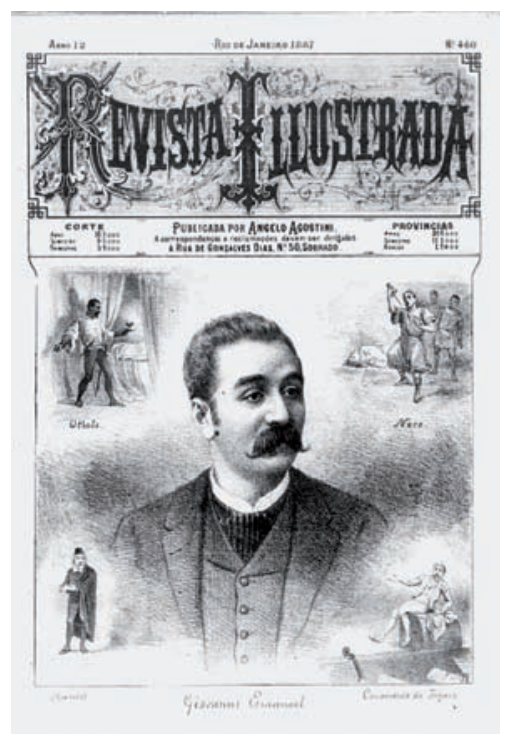

Os retratos, apresentados em todas as capas da revista paranaense, também estão presentes em alguns números nas páginas internas. Esse tipo de imagem tem relação complementar com a seção "Galeria Paranaense", que apresentava descrições biográficas de personalidades do cenário paranaense. Feitos por vezes com base em referências fotográficas, como no caso de Generoso Marques dos Santos, ${ }^{64}$ ou baseados em outros desenhos já publicados, como no caso de Manoel Eufrásio Correia, ${ }^{65}$ esses retratos, assinados por Figueras, exploravam as possibilidades da litografia relacionadas ao uso do lápis e do bico de pena para a obtenção de meios-tons. Foram contemplados por essa coluna os políticos paranaenses Generoso Marques dos Santos, Manoel Eufrásio Correia, Manoel Alves de Araújo, Manoel Francisco Correia, Jesuíno Marcondes d'oliveira, Agostinho Ermelino de Leão e João José Pedrosa. Também tiveram suas biografias e retratos publicados os religiosos Dom Lino

\footnotetext{
${ }^{63}$ REVISTA ILLUSTRADA. Rio de Janeiro, ano 12, nº 460, 1887, p. 1.

${ }^{64} \mathrm{O}$ editor afirma não ter sido possível obter fotografia atualizada do personagem Generoso Marques dos Santos, visto ter este se negado a fornecer esse material. Em: REVISTA do Paraná. Curitiba, ano 1, nº 1, 23 out. 1887, p. 2.

${ }^{65} \mathrm{O}$ editor afirmou, no início do texto que se refere ao Sr. Dr. Manoel Euphrasio Correia, ter utilizado como referência uma imagem veiculada na publicação intitulada "Galeria dos Políticos Proeminentes do Paraná”. Em: REVISTA do Paraná. Curitiba, ano 1, no 2, 30 out. 1887, p. 2.
} 
Deodato Rodrigues de Carvalho (bispo de São Paulo), o Padre Julio Ribeiro de Campos e o poeta Leôncio Correia. ${ }^{66}$

O retrato do Conselheiro Manoel Alves de Araújo (Figura 4) é um exemplo desse tipo de imagem, que, ao contrário das caricaturas, privilegiava certa fidelidade à estrutura anatômica e fisionômica do modelo representado, numa abordagem mais realista e de acordo com as convenções da época, que tinham na semelhança ou na aproximação com o real o parâmetro privilegiado de qualidade artística. O enquadramento oval, interrompido na altura do busto, tem relações com um formato bastante comum na época, utilizado em retratos pintados ou fotografados, afixados nas paredes das casas e edifícios públicos ou, de formato menor, usados ao pescoço como pingentes. O tipo de corte feito na imagem guarda também semelhanças com os bustos em bronze, tradicionais do campo da escultura, que apresentavam muitas vezes finalização arredondada na parte inferior.

Figura 4 - Retrato de Manoel Alves de Araújo ${ }^{67}$

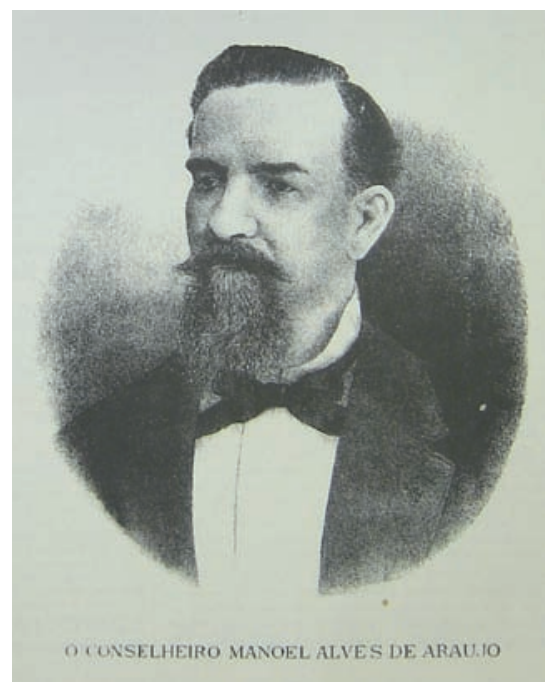

Foram também objetos de atenção da coluna "Galeria Paranaense" localidades da região, instituições de ensino, temas ligados à história do Paraná e

\footnotetext{
${ }^{66}$ REVISTA do Paraná. Curitiba, ano 1, no 4, 15 nov. 1887, p. 1-3 e 5-8.

${ }^{67}$ REVISTA do Paraná. Curitiba, ano 1, nํ2, 30 out. 1887, p. 1.
} 
mesmo costumes da imigração europeia. Alguns desses artigos vinham acompanhados de ilustrações, com as quais se estabelecia uma relação dialógica: por vezes as imagens eram motivadoras dos textos, por vezes os complementavam. Esse é o caso do retrato de corpo inteiro de D. Francisca Munhoz, aluna da aula de Desenho e Pintura de Mariano de Lima (Figura 5), realizado pelo também seu aluno Manoel Azevedo da Silva Neto. Segundo o texto que o acompanha, trata-se do ambiente da referida aula, nas dependências do Instituto Paranaense, embora se assemelhe mais a uma cena doméstica, o que se percebe pelo vaso sobre a mesa coberta com a toalha e pelas crianças que rodeiam a pintora. Ao contrário dos retratos vistos anteriormente, que focavam figuras eminentes da sociedade paranaense, explorando suas biografias no texto, nesse caso a imagem da figura feminina é mais um pretexto para o autor discorrer sobre a experiência da aula de Mariano de Lima e sobre seus alunos, que são bastante elogiados pelo autor.

Figura 5 - Francisca Munhoz no atelier ${ }^{68}$

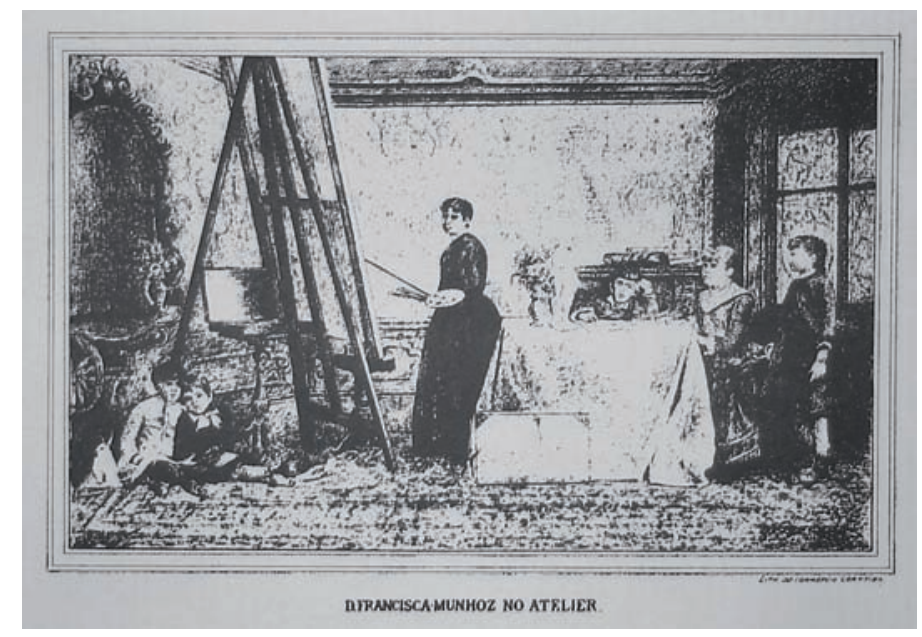

No papel de ilustrador da revista, Figueras produziu em litografia imagens consideradas por Carollo ${ }^{69}$ como preciosos documentos da iconografia local. É o caso das vistas de Curitiba e de São José dos Pinhais, imagens reproduzidas com base em aquarelas de John Henry Elliot $(1809,1888)$, explorador,

\footnotetext{
${ }^{68}$ REVISTA do Paraná. Curitiba, ano 1, nํ1, 23 out. 1887, p. 5.

${ }^{69}$ CAROLLO, op. cit.
} 
cartógrafo e desenhista conhecido como o "pintor da velha Curitiba". Essas litografias estão entre as poucas capazes de revelar a Curitiba da época. Uma das contribuições do artista para o periódico, intitulada Curitiba em 1855 (Figura 7), é considerada a primeira litografia gravada na capital da Província, executada com base em um desenho a guache (Figura 6), de autoria de John Henry Elliot.

Figura 6 - John Elliot. Vista de Curitiba em 1855, Casa da Pólvora ${ }^{70}$

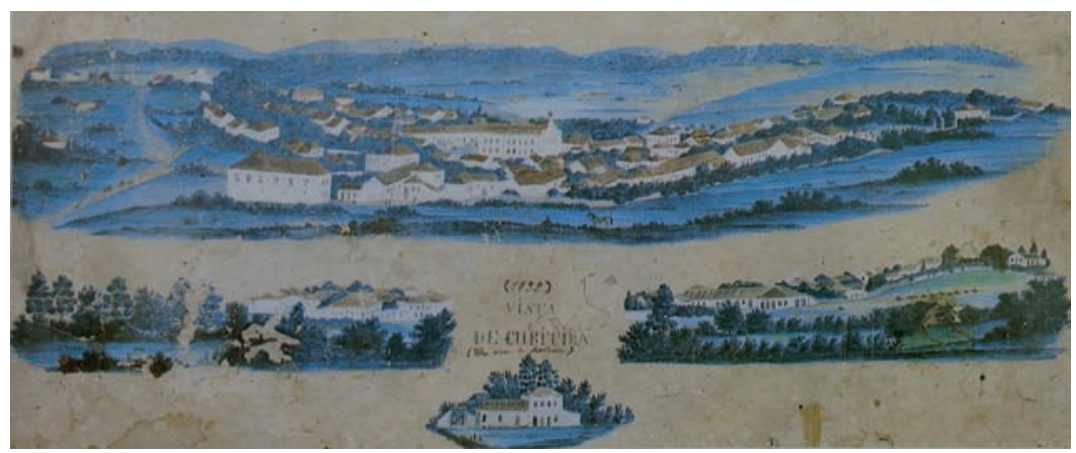

Figura 7 - Curitiba em $1855^{71}$

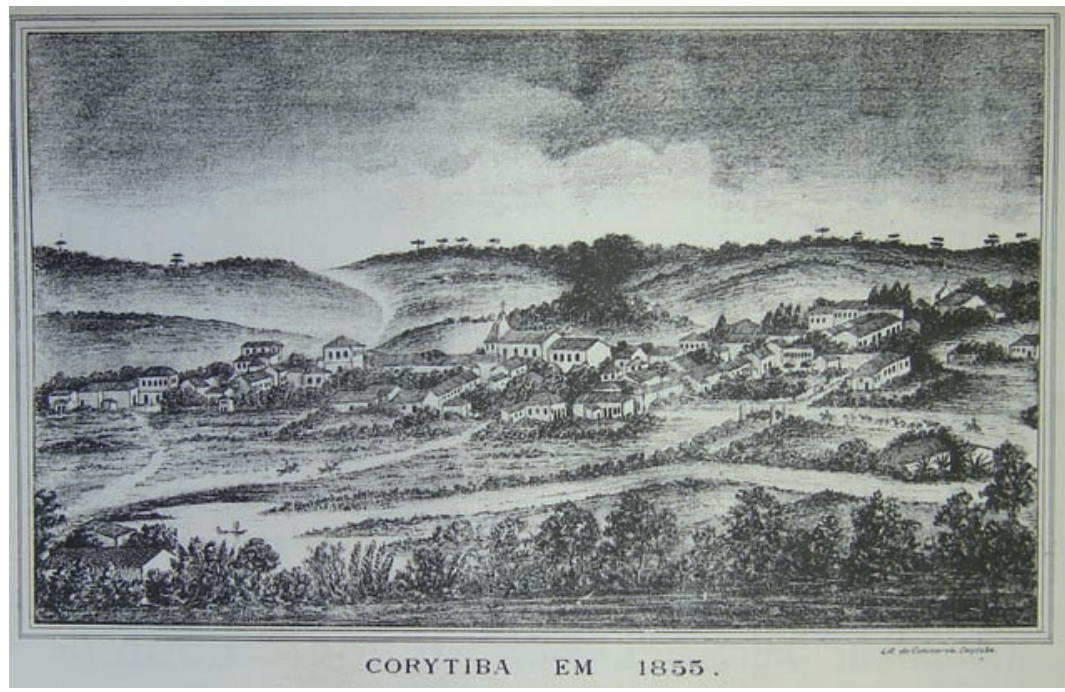

${ }^{70}$ ELLIOT, John Henry. Vista de Curitiba, em 1855, Casa da Pólvora. 1855. Pintura, guache e lápis de cor sobre papel, dimensões: 59 X $26 \mathrm{~cm}$, Acervo Museu Paranaense, nº de tombo 1035.

${ }^{71}$ REVISTA DO PARANÁ. Curitiba, ano 1, n² 2, 30 out. 1887, p. 4. 
Este original foi considerado perdido por alguns historiadores como Carneiro ${ }^{72}$ e Carollo. ${ }^{73}$ Uma publicação referente à Pinacoteca Paranaense, seção do Museu Paranaense criada em 1886, menciona que, depois de sua instalação em sede definitiva, em 1906, teria sido adquirida "uma coleção de vistas de Curitiba, sendo uma de 1855, sem nome de autor, outra de 1865, de Elliot, outra de 1888, de Hundenthal, todas copiadas a pastel pelo notável artista Alfredo Andersen, dos velhos originais do Museu". ${ }^{74}$ No entanto, uma pintura a guache intitulada "Vista de Curitiba, em 1855, Casa da Pólvora", com autoria atribuída a John Elliot, foi localizada como parte do acervo do Museu Paranaense (Figura 6), constando com o número de tombo 1035. A técnica utilizada, a inscrição "1855" no interior da imagem e o fato de integrar o acervo do Museu nos levam a crer que se trata da imagem original, utilizada por Figueras para elaborar sua imagem. O próprio editor da Revista do Paraná comentou, em texto que acompanha a imagem, que o desenho fora "obsequiosamente cedido pelo Diretor do Museu Paranaense, Snr. Commendador Manoel Ricardo Carneiro", ${ }^{75}$ o que indica que a imagem integrava esse acervo já naquela data e que Figueras a teve em suas mãos quando trabalhou em sua litografia.

Ambas as imagens, a original (Figura 6) e a litografia (Figura 7), trazem uma vista panorâmica da cidade, tomada com base em um ponto de vista elevado, a segunda se restringindo ao conjunto central representado na primeira. É curioso perceber a inversão da imagem típica das técnicas de gravura, o que leva a concluir que Figueras, tendo a aquarela nas mãos, realizou uma cópia direta do original, sem se preocupar com esse efeito de espelhamento que ocorre após a impressão da matriz. Isso fica evidente quando observamos, por exemplo, a torre da igreja ao centro e também a igreja que se localiza no lado esquerdo da aquarela, no alto da imagem, e que aparece no lado direito da litografia. Também se percebe certa liberdade na organização da perspectiva, não estando os vários prédios exatamente nos mesmos ângulos nas duas representações.

No caso da imagem gravada, o traçado, realizado com lápis litográfico, explora as passagens suaves de luz e sombra, mantendo os contornos mais

\footnotetext{
${ }^{72}$ CARNEIRO, David. John Henry Elliot e outros pioneiros americanos no Paraná. Curitiba: Serviço de Divulgação e Relações Culturais dos Estados Unidos da América, 1963. Folheto. Acervo Biblioteca Pública do Paraná.

${ }^{73}$ CAROLLO, op. cit.

${ }^{74}$ MUSEU de Arte Contemporânea do Paraná. Um século da Pinacoteca do Museu Paranaense. Curitiba, 1976. Catálogo de exposição. Acervo do Círculo de Estudos Bandeirantes.

${ }^{75}$ CORYTIBA em 1855. In: REVISTA DO PARANÁ, Curitiba, ano 1, nº 2, 30 out. 1887, p. 3.
} 
definidos apenas para os elementos arquitetônicos. Na paisagem, que representa uma Curitiba no início de seu processo de urbanização, percebe-se em uma linha central um amontoado de construções de grande porte, com destaque para a igreja no centro da imagem. Alguns caminhos fazem a ligação entre as construções. Os tropeiros, os quais reconhecemos pela formação (uma fila com dois cavaleiros nas extremidades e as mulas ao centro), se conduzem em direção à cidade, provavelmente pela estrada do Arraial ou talvez do Alto da Glória. ${ }^{76} \mathrm{Na}$ parte inferior, pode-se ver o rio com algumas casas e uma canoa. A parte superior da imagem é reservada para o céu e, no horizonte, algumas araucárias, ausentes na imagem original, podem claramente ser identificadas pelo ímpar formato de sua copa. O restante da vegetação é composto de áreas mais escuras e indefinidas, distribuídas junto ao rio, na base da imagem, entre as construções.

A Curitiba ali representada não passa de um pequeno povoado observado do alto, provavelmente do ponto de vista dos tropeiros que por ali passavam. Situava-se "num teso, assaz ondulado e banhado por diversos pequenos tributários boraes das cabeceiras do caudaloso Yguaçu (...), elevando-se no quadro sub-urbano, em um local regado pelo ribeirão Baryguhy", ${ }^{77}$ que aparece representado em primeiro plano nas imagens. Por meio do texto descritivo que acompanha a imagem litográfica, tomamos conhecimento de algumas de suas características, tomadas pelo autor de estatística do ano de 1855, por exemplo, de que tinha em sua malha urbana "27 quarteirões, cuja população attingia a 5819 almas, sendo 47 estrangeiros". Possuindo 308 casas, 4 igrejas, uma cadeia e um prédio adequado ao funcionamento da Assembleia Provincial, já contava com " 73 commerciantes, 1 ourives, 6 alfaiatarias, 9 sapatarias, 3 açougues, 1 padaria, além de differentes casas de quitanda e de uma Typografia, onde se imprimia o Dezenove de Dezembro"..$^{78}$

Também podemos citar imagens da Matriz Colonial da Praça Tiradentes, entre outras, de igual importância, executadas por Figueras (figura 8). No texto que a acompanha, o autor diz se tratar de cópia litográfica de uma fotografia da Igreja Matriz de Curitiba, demolida em 1876 por apresentar problemas em sua estrutura, ${ }^{79}$ apontando para o uso desse tipo de referencial na constituição da litografia.

\footnotetext{
${ }^{76}$ REVISTA do Paraná. Curitiba, ano 1, nº 2, 30 out. 1887, p. 6.

${ }^{77}$ Idem, p. 3.

${ }^{78}$ Idem, p. 6.

${ }^{79}$ REVISTA do Paraná. Curitiba, ano 1, nº 3, 06 nov. 1887, p. 5-6.
} 
Figura 8 - Igreja Matriz de Curitiba ${ }^{80}$

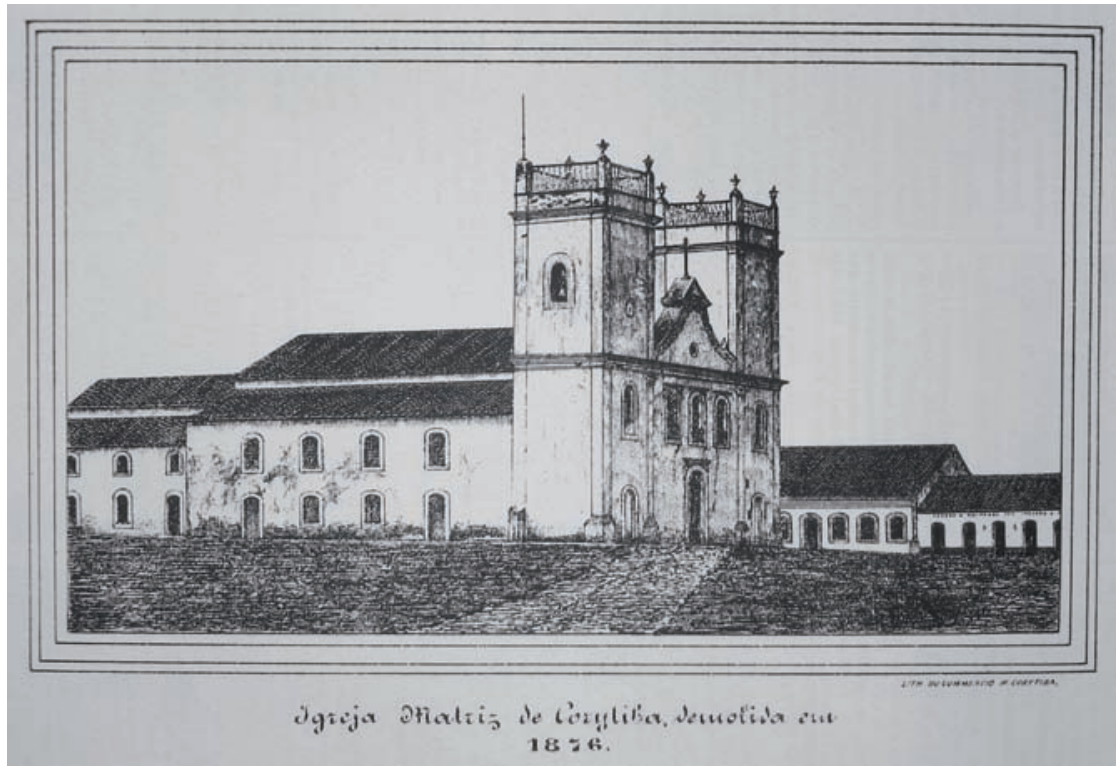

Embora Narciso Figueras tenha sido o responsável pela gravação das imagens nas pedras litográficas, muitas vezes, como no caso das aquarelas de Elliot, o fez baseado em imagens fornecidas por outros autores. Foi o caso da gravura intitulada "Combate entre o Cormorant e a Fortaleza de Paranaguá" (Figura 9), que retrata um episódio histórico ocorrido no litoral paranaense quando, como decorrência da proibição, em 1831, do tráfico de africanos no Brasil, teve início, em 1850, o patrulhamento repressivo da costa brasileira com auxílio da Inglaterra. Naquele ano, o cruzador inglês Cormorant perseguiu três navios negreiros em direção ao porto de Paranaguá. Isso provocou reação da população e dos governantes da cidade, que se sentiram ameaçados, resultando numa batalha das forças locais contra o navio inglês, para o que foi mobilizada a Fortaleza de Paranaguá, situada na Ilha do Mel, que se localiza à entrada da baía de Paranaguá. ${ }^{81}$

\footnotetext{
${ }^{80}$ Idem, p. 5.

${ }^{81}$ MARTINS, Romário. História do Paraná. $2^{2}$ edição. Curitiba; São Paulo; Rio de Janeiro: Editora Guaíra, 1939, p. 234-236.
} 
Figura 9 - Combate entre o Cormorant e a Fortaleza de Paranaguá ${ }^{82}$

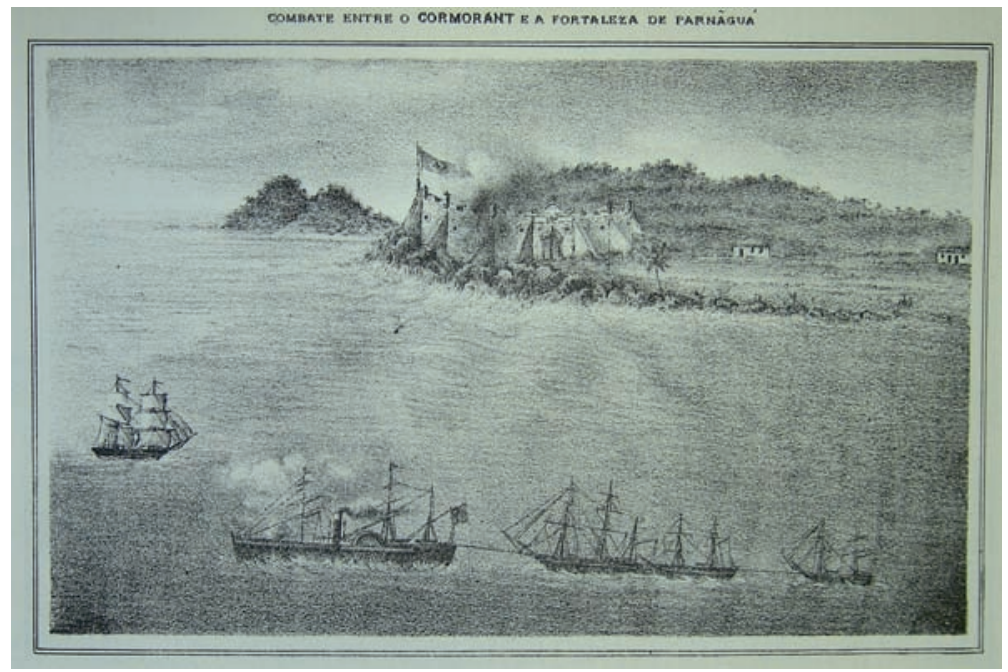

No final do artigo complementar à imagem, o autor esclarece ao leitor o processo coletivo de constituição dela, que contou com a finalização competente das mãos de Figueras:

E o desenho, que representa o Combate travado entre o "Cormorant" e a Fortaleza de Paranaguá, o devemos aos habilíssimos lápis dos Srs. Commendador Manoel Ricardo Carneiro, que se dignou a delinear os contornos da Fortaleza, Capitão Joaquim Natividade da Silva, que ministrou-nos com precisão as cardinaes da Ilha do Mel, e Francisco Castello Branco, 1ํㅡㄹ Escripturario da Thesouraria de Fazenda, que com rara e notável maestria desenhou, com o auxilio dos dados mencionados, o Quadro Graphico, cuja gravura se acha litographada no verso da $3^{\text {a }}$ pagina desta revista. ${ }^{83}$

Joaquim Natividade da Silva também é o autor da gravura que representa a localidade de Guaraqueçaba, publicada na edição de número 6 da revista. ${ }^{84}$ Esse cuidado em revelar o processo de feitura da imagem, tomado por Nivaldo Braga, se revela com relação a outra litografia, que leva o título de "Resalto da Bulha do Rio Ivahi" (Figura 10), publicada na mesma data:

A paizagem, que representa a gravura inserta no verso da $2^{2}$ Secção desta Revista, devemol-a ao habilíssimo lápis da Exma Sra. D. Maria Christina Lustosa de

\footnotetext{
${ }^{82}$ REVISTA do Paraná. Curitiba, ano 1, nº 4, 15 nov. 1887, p. 4.

${ }^{83}$ Idem, p. 8.

${ }^{84}$ REVISTA do Paraná. Curitiba, ano 1, no 6, 01 dez. 1887, p. 5.
} 
Carvalho, virtuosa e talentosa Esposa do Snr. José Leite de Carvalho, Negociante da Praça do Rio de Janeiro: é uma copia fiel que tão illustre Paranaense reproduzira em sua meninice escolar, do desenho com que o Snr. Engenheiro Gustavo Rumblsberber (...) brindara, ao regressar de sua alfanosa Exploração do Ivahy, ao Snr. Tenente Coronel Antonio Ricardo Lustosa de Andrade (...). ${ }^{85}$

Figura 10 - Resalto da Bulha no Rio Ivahi, alias Ubahy ${ }^{86}$

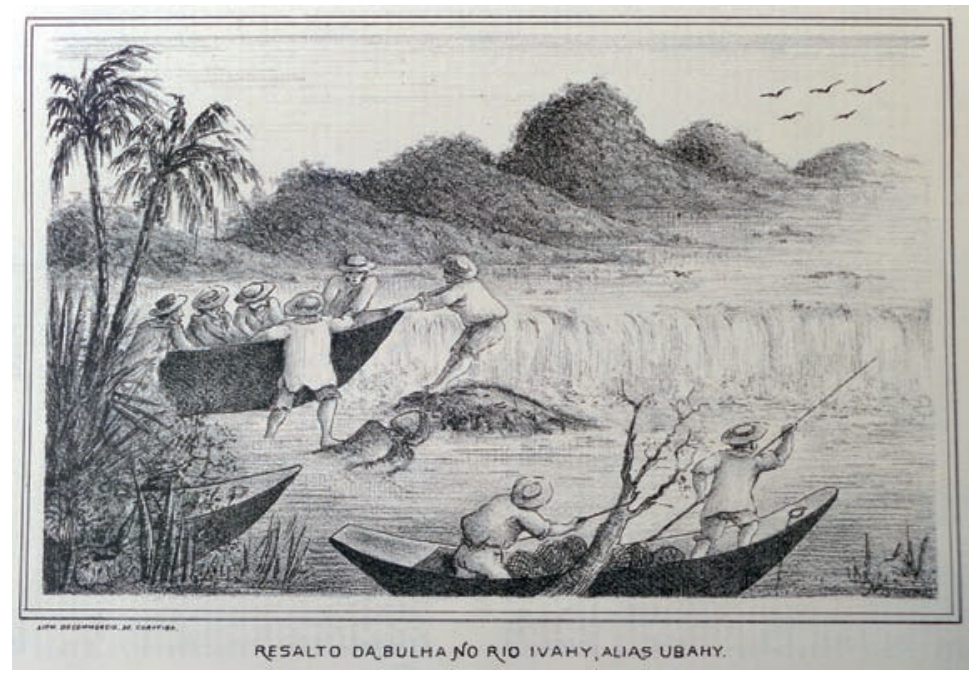

Embora em sua maioria as imagens publicadas na Revista do Paraná estejam assinadas ou identificadas por meio dos textos que a elas se referem, outras ali presentes, como a intitulada "São José da Boa Vista" 87 ou "São José dos Pinhais", integrante do último número da Revista, ${ }^{88}$ trazem apenas a identificação da Lithographia do Commercio. Entretanto, todas elas trazem a marca do lápis litográfico de Narciso Figueras, o qual contribuiu para o surgimento de um novo modelo de periódico no contexto paranaense e para a inserção da imagem no dia a dia do cidadão comum.

\footnotetext{
${ }^{85}$ Idem, p. 3.

${ }^{86}$ Idem, p. 4.

${ }^{87}$ REVISTA do Paraná. Curitiba, ano 1, nº 5, 22 nov. 1887, p. 5.

${ }^{88}$ REVISTA do Paraná. Curitiba, ano 1, nº 7, 17 dez. 1887, p. 4.
} 


\section{Considerações finais}

Procurando se inserir nos processos de modernização então em curso e se baseando nos moldes de periódicos já em circulação na Europa, nos Estados Unidos e em centros brasileiros como Rio de Janeiro, São Paulo e Recife, o projeto de Nivaldo Braga ofereceu aos seus leitores elementos que colaboraram para a construção de um hábito de leitura associativo entre texto e imagem. Assumindo um caráter regionalista, a Revista do Paraná buscava dar visibilidade às localidades, às personalidades e aos acontecimentos paranaenses, não deixando de comentar temas relacionados à política ou à sociedade da época.

Narciso Figueras, assim como outros artistas europeus que desembarcaram em províncias brasileiras, ao dispor, juntamente com seus colaboradores, dos recursos de meios-tons possibilitados pelo lápis litográfico, baseou-se em referenciais iconográficos que variavam entre pinturas em aquarela ou guache, desenhos fornecidos pelos leitores, fotografias e mesmo reproduções já publicadas em outras obras impressas.

As litografias apresentadas pela Revista do Paraná estão entre as primeiras imagens de um conjunto iconográfico significativo para a memória visual do Paraná oitocentista ao retratar o cotidiano, os costumes, as paisagens e as construções do período.

Assim, malgrado sua duração relativamente curta, a Revista do Paraná captou e criou imagens simbólicas e consequentemente as perpetuou para as gerações futuras, dando início à sua disseminação a um público mais ampliado no ambiente cultural paranaense e ao registro iconográfico de nossa história por meio da imprensa.

Artigo recebido para publicação em 09/11/2015

Artigo aprovado para publicação em 30/03/2016 